\title{
Rewilding Forestry
}

Dandy, Norman; Wynne-Jones, Sophie

\section{Forest Policy and Economics}

\author{
DOI: \\ 10.1016/j.forpol.2019.101996
}

Published: 01/12/2019

Peer reviewed version

Cyswllt i'r cyhoeddiad / Link to publication

Dyfyniad o'r fersiwn a gyhoeddwyd / Citation for published version (APA):

Dandy, N., \& Wynne-Jones, S. (2019). Rewilding Forestry. Forest Policy and Economics, 109, [101996]. https://doi.org/10.1016/j.forpol.2019.101996

\footnotetext{
Hawliau Cyffredinol / General rights

Copyright and moral rights for the publications made accessible in the public portal are retained by the authors and/or other copyright owners and it is a condition of accessing publications that users recognise and abide by the legal requirements associated with these rights.

- Users may download and print one copy of any publication from the public portal for the purpose of private study or research.

- You may not further distribute the material or use it for any profit-making activity or commercial gain

- You may freely distribute the URL identifying the publication in the public portal ?
}

Take down policy

If you believe that this document breaches copyright please contact us providing details, and we will remove access to the work immediately and investigate your claim. 


\title{
Rewilding Forestry
}

Norman Dandy and Sophie Wynne-Jones

Sir William Roberts Centre for Sustainable Land Use, Bangor University, Gwynedd, Wales, UK

\begin{abstract}
Rewilding has become highly popular amongst conservationists, ecologists, geographers and others, but interest is considerably less obvious amongst foresters. Whilst overall the amount of research focused on rewilding continues to grow rapidly, very few papers published within core forestry journals engage with the concept. In this commentary, we offer some potential explanations for this lack of engagement which include rewilding's early focus on animals (especially carnivores), its conceptual overlap with restoration, and the potentially profound implications for forestry practice and policy consequent to embracing the approach. Despite these issues and barriers, we argue for greater research attention to be given to rewilding by forest scientists. Increased interaction has the potential for significant mutual benefits. Foresters can bring a range of established insights to the debate that would inform key aspects of contemporary rewilding policy and practice, such as ecological succession dynamics and silvicultural approaches to transition. In response, rewilding has considerable potential for refreshing and reframing aspects of forestry policy and practice, including approaches to resilience.
\end{abstract}

Keywords: Rewilding; Forest restoration; Forest science; Forestry journals

\section{Commentary: Rewilding Forestry}

The concept of rewilding has gained significant popularity amongst conservationists and ecologists (Pettoreilli et al. 2019), as it has with academic geographers (Biermann and Anderson 2017) and environmental historians and philosophers (Jørgensen 2015; Drenthen 2018). Use of the term in titles and abstracts of scientific papers has increased enormously, commonly featuring in conservation-oriented life sciences journals. Jepson noted 45 academic papers and more than 200 media articles in a single year (Jepson 2016). A Web of Science search in 2019 shows this trend is continuing - identifying more than 200 research articles and reviews with rewilding as their subject, with 2018 being another record year. Major rewilding projects are held up as conservation best practice (Monbiot 2013) and an increasing number of conservation NGO's have explicit rewilding policies (e.g. John Muir Trust 2015; Woodland Trust 2017), with widening interest evident across land-use policy circles (Wentworth and Alison 2016).

In stark contrast, this observed interest in rewilding has seemingly not been mirrored within forest research. Just five of the above mentioned $200+$ papers located by WoS are in forestry 
journals ${ }^{1}$. A direct search of more than 10 leading forestry journals ${ }^{2}$ uncovered just 14 papers using the term rewilding - only six engaging meaningfully with the concept (i.e. beyond a single occurrence of the word in a reference list or conclusion). Given the importance of forests to the global conservation agenda, what might explain this apparent oddity? And what, if anything, should be done about it?

\subsection{What is rewilding?}

Whether or not forest researchers are seen as engaging with rewilding depends significantly on what we consider rewilding to be. Analysis of the concept is wide-ranging and whilst there is certainly no definitional consensus, contemporary research suggests some core characteristics. It is not the purpose of this Commentary to review this literature (see Gammon 2018; Jørgensen 2015; Lorimer et al 2015), however it is useful to reiterate its parameters in order to understand its relationship to forestry. Rewilding has evolved considerably as a concept over a relatively short period, and the structure of our summary reflects that timeline.

At the outset, in the early 90's and 2000's, rewilding was pitched as a radical approach to restoration, proposed by North American scholars and activists, aiming to promote connectivity between large core wilderness areas, and reintroduce keystone species to ensure trophic function (Foreman 2004). Initially much emphasis was placed on carnivores (e.g. wolves in Yellowstone National Park). However, as rewilding practice has developed it has increasingly included the reintroduction or 'de-domestication' of other species, especially herbivores (Lorimer and Driessen 2013). Whilst the importance of trophic completeness, and associated ecological functionality, has remained a core feature of rewilding, early conceptualisations were criticised for their emphasis on wilderness - as discrete conservation space - and historic reference points (Ward 2019). More recent understandings have consequently evolved to focus on the condition of wildness and ambitions to work towards 'future natures' (Lorimer and Driessen 2016), although earlier critiques can still be brought to bear on current practice in some instances. Rewilding has also expanded to include markedly anthropogenic places / landscapes, and in turn brought attention to the position of humans within rewilding - building on decades of debate regarding the juxtaposition of humans and the 'wild'.

Refining earlier interpretations, Lorimer et al. (2015), contrast rewilding's emphasis on ecological integrity with traditional 'compositional' approaches. In these terms, rewilding is not only associated with lost species but also efforts to reinstate successional dynamics and abiotic processes that have previously been arrested by human intervention seeking to preserve specific 'valued' features (see Sandom and Wynne-Jones 2019). Arts et al. (2015) add to this by identifying the enhancement of natural autonomy as a pillar of rewilding. This point is echoed by many recent analyses, which emphasise ambitions for 'self-willed'

\footnotetext{
${ }^{1}$ Our definition of 'forestry journals' follows bibliographic analyses, specifically Vanclay (2008) and Malesios, C. and G. Arabatzis (2012).

${ }^{2}$ Searches were undertaken of all forestry journals except those with strong specific focus (e.g. wood science, plant genetics, forest meteorology, pathology) entailing an unlikely engagement with rewilding. Journals searched were: Forest Ecol. Manag; Forestry; Forest Sci; Forest Policy Econ; Ann Forest Sci; Int Forest Rev; Can J Forest Res; New Forest; Forests; Urban For Urban Gree; Silva Fenn; J Forest; Scand J Forest Res. Eur J Forest Res.
} 
ecosystems (Fisher and Parfitt 2016), wherein human intervention is minimised (Wentworth and Alison 2016; Jepson and Shepers 2016). It has also become a guiding principle for some rewilding organisations:

Natural processes drive outcomes: Rewilding seeks to reinstate natural processes for example, the free movement of rivers, natural grazing, habitat succession and predation. It is not geared to reach any human-defined optimal point or end state. It goes where nature takes it. (Rewilding Britain 2017)

As such, for some rewilding has been distinguished from restoration, understood primarily as a managed process of restoring and reinstating lost features, and proposed as a substantively different way of doing conservation. Nonetheless, there is still considerable debate as to whether rewilding is really departing from past approaches (Arts et al. 2015; Hayward et al. 2019). There is also discussion about the appropriate level of human presence within rewilding projects, not only regarding the extent and acceptability of management interventions, but also whether human settlement and activities are a desirable component of rewilded landscapes. Linked to this, there are concerns regarding the impact of rewilding on people, including the socioeconomic and wellbeing consequences of land-use change (e.g. Wynne-Jones et al. 2018). Despite these ongoing debates, areas of consensus are emerging These are that rewilding is guided foremost by an aspiration to enhance ecological function and trophic complexity and that this should be achieved by means of reductions in human management (Biermann and Anderson 2017; Torres et al. 2018).

\subsection{Rewilding out of focus?}

From this brief overview of the key features of rewilding, a number of potential explanations emerge for the apparent lack of engagement within forest science. First is the high profile given to animal reintroduction as a key feature of academic discussions (perpetuated within media and science communication coverage of rewilding, e.g. Nesbit 2018) and the relative side-lining of plants and their associated ecological functions. This connects to rewilding's objective for richer trophic dynamics, with attention centring on the functions performed (e.g. predation; herbivory) and trophic layers constituted by faunal species. Foresters, by and large, are not overly concerned with carnivores or other predators. They do take a strong interest in herbivores, although rarely to advocate their reintroduction. The negative impacts of deer, rabbits and other herbivores being a well documented element of forest science. Despite the apparent centring of rewilding debate on animals, aspirations for ecological integrity also extend to encompass an interest in vegetation succession for many contemporary rewilding projects, which we return to below.

Another critical reason, potentially explaining why forest researchers haven't embraced rewilding is the emphasis placed on the reduction in human management and aligned promotion of non-human autonomy as a key feature of rewilding. In some ways forest science (and management) can be considered as the ongoing pursuit of understanding how humans can most effectively intervene in natural processes to maximise human benefit! For foresters, rewilding could involve living with some phenomena that they have long been seeking to control, are deeply uncomfortable for them, and in many cases antipathetic to the 
commercial and other forestry practices that drive forest science. We have already mentioned herbivory, and rewilding could require profound changes in the level of tolerance of browsing! At this point should be noted, however, that where rewilding also involves the introduction of predators, browsing pressure could be checked (indeed this has long been an explicit argument for predator reintroductions). It may also be possible to choose how and when to (re)establish these uncomfortable processes - the Carrifran Wildwood project for example currently excludes browsers through a substantial deer fence (Prior and Brady 2016). Perhaps even more unsettling and difficult than browsing, however, would be the need for foresters to tolerate 'damaging' abiotic processes such as wind and fire to a far greater extent than currently. The role of fire in forest regeneration is a core debate in certain forest science and management circles, but tolerating it (or at least not actively abating it) in locations such as Northern Europe could well be a challenge for existing foresters. Equally troubling to tolerate would be forest pest or disease outbreaks - another major driver of contemporary forest science. Here we encounter direct conflicts between aspirations to unleash nature's autonomy and forestry activities which exert human influence over biological and ecological processes to gain resources. Making an argument for a new approach to forestry that tolerated herbivory, fire, wind and pest/disease outbreaks would require a strong commitment to the rewilding concept, and probably a fundamental rethink of what forest science and management seek to achieve.

Conceptual clarity matters in research and given the much-debated overlap between understandings of rewilding and restoration, forest scientists may simply not see the relevance of the new term for actions and studies they have long been undertaking under the banner of 'forest restoration'. Forest restoration has been a central feature of sustainable forest management for many years and its profile within forestry journals shows a long-lived and increasing interest. In particular, rehabilitation (described by Stanturf et al. (2014) as the restoration of "species composition, structure, or processes to an existing, but degraded ecosystem" p. 294) and reconstruction ("restoring native plant communities on land recently in other resource uses" p. 294) appears to occupy much of the conceptual territory sought by contemporary rewilding. This is especially true where forests are viewed as existing in an inappropriately humanised state, as can frequently be the case with commercial plantation forests. Why would foresters need to 'rewild' when they are already 'restoring'?

\subsection{Bringing rewilding in to focus}

We have outlined some potential explanations for the apparent limited engagement with rewilding in the forestry sector. But should forest researchers take more notice of it and contribute seriously to the policy, research and practice debates surrounding rewilding? We argue there is, in fact, much to be gained from the interaction of forest science and rewilding.

There are a number of parallels between long-standing elements of rewilding interest and forest science. Woodland habitat connectivity, for example, and an interest in 'intact' forest areas directly echo aspects of rewilding's early key features. However, perhaps the most fundamental driver of interaction should be rewilding's increasing focus on ecological integrity and consequent interests in successional dynamics, herbivory, the enhancement and expansion of forest ecosystems (Ceaușu et al. 2015; Sandom and Wynne-Jones 2019). This 
generates clear overlap between the future-oriented ambitions of at least some forest scientists and rewilders. In some instances rewilding practice is leading the way here. For example, in the UK projects such as the Carrifran Wildwood, Trees for Life, Wild Ennerdale (Browning 2019), and Cairngorms Connect, which have all been lauded as pioneers of rewilding ${ }^{3}$, include substantive aspirations to reinstate natural forest processes and increase levels of tree cover. Indeed, old growth forests across Europe, such as Białowieża, are held up as icons of what rewilding is seeking to achieve (Monbiot 2013). Equally, rewilding is being implemented on former conifer plantations, for example at Glenlude (John Muir Trust), as part of a reconsideration of intensive management imperatives. There is clear synergy here with long-standing forest restoration programmes such as, in the UK, the restoration of plantations on ancient woodland sites (PAWS) scheme of the UK's Forestry Commissions (Harmer \& Kiewitt 2005).

These cases highlight that those state and non-governmental organisations which draw consistently on forest science and practice are increasingly participating in and engaging with projects labelled as rewilding. This provides further rationale for the engagement of forestry and rewilding, as we see a growing demand for knowledge that effectively integrates the two and enables forestry organisations (forestry knowledge users) to navigate this emergent field. A more active dialogue between rewilding and forest restoration is surely critical. Forest scientists should be able to strengthen the grounding of rewilding: contribute to setting its parameters, boundaries, and practice.

A number of other knowledge areas familiar to the forest sciences could and should be brought to bear on rewilding. For example, tensions within rewilding circles around the appropriate level of human presence and intervention connect to longstanding debates within forestry regarding the extent of anthropogenic impact on the landscape. This is particularly relevant in the European context where environmental historians have explored the function and form of forests in some depth. Forest researchers have also contributed strongly to analysis at the interface of biological diversity, forest management and aesthetic preference (e.g. Gobster 1999) - an area of debate within contemporary rewilding (e.g. Prior \& Brady 2016). Forest scientists are also well drilled in thinking about and analysing the long-term, giving consideration to ecological succession and timeframes relevant to tree growth. In this regard, certain silvicultural approaches, such as continuous cover forestry or low-impact silvicultural systems, could usefully inform rewilding projects in their immediate approaches to transition from even-aged species diversity poor forests to forests more sympathetic to long term 'natural' autonomy.

\subsection{Rewilding forestry}

Rewilding can, vice versa, potentially do much to inform contemporary forest science and management. Rewilding has provided significant impetus and energy to the conservation sector in recent years and it could have a similar effect within forestry. It has the potential to provide a strong critical lens through which to reflect on established forest practices and concepts. The existence of well-established discourses around forest restoration, and the strong anthropocentric rhetoric underpinning forest policy that increasingly seeks to

\footnotetext{
${ }^{3}$ See https://www.rewildingbritain.org.uk/rewilding/rewilding-projects/
} 
constitute forests in terms of ecosystem services to people for example, may in fact be constraining management options. Rewilding could provide the 'radical vision' and inspiration foresters need in a similarly progressive way as Jepson advocates for conservationists (Jepson 2015).

The emphasis on nature's autonomy - and a nature-led approach to 'restoration' - within rewilding has particular potential to provide a valuable steer and challenge to forest science and management. Having noted above that this may be an important barrier to forest scientists engaging with rewilding, it is also important to acknowledge the significant impact that engagement in this contemporary conceptual debate could potentially have. Such a framing may in fact support the establishment of more resilient forests in the longer term including a resilience within the forestry sector itself generated by improved tolerance and adaptive capacity within its values, standards, and institutions. It may also underpin further development of management options such as natural flood management - which is currently something of a hybrid between a human-engineered process and natural autonomy.

For all this discussion of 're-framing' forest science (and management) and 'grounding' rewilding, it is important not to simply reinforce conceptual and practical divisions between them. The objective must be identifying and analysing area of synergy and mutual benefit. There are substantial unanswered questions regarding what the forests and forest management systems might look like that meet the demands of the rewilding agenda whilst also producing the material and cultural benefits (e.g. timber, recreation, flood protection) that contemporary forestry currently supplies. Carbon sequestration and management is at the core of current forest science debates: what are the implications of the rewilding approach in relation to these analyses?

It may not be clear precisely what rewilding is and foresters may feel they've been doing for some time what rewilders claim as theirs. However, whatever the reasons for the apparent lack of interest in rewilding amongst forest scientists, there seems substantially more to gain from participating in the contemporary debates than from ignoring them or letting them go on unchallenged. The emergence of rewilding to date manifests itself as another instance of the common problem of disciplinary and sectoral divisions - between two areas, forestry and conservation, that are profoundly interlinked and should be closely integrated. Moving forward it appears critical for forest scientists to engage more strongly and directly with rewilding, following the lead taken by some practitioners as noted here. The language of rewilding has considerable potential to bring foresters, conservationists and other stakeholders closer together - through recognising overlap and enabling conversations about shared goals. Rewilding can provide a conduit and framing via which foresters - often simplistically identified as commercial and production oriented - can demonstrate and explain their long-standing conservation efforts and achievements. It can refresh analysis of and debates around alternative silvicultural systems - such as continuous cover forestry - that can foster the ecological complexity and autonomy demanded by rewilding.

Without those involved in forest science appraising themselves of the debates, concepts and drivers intrinsic to rewilding, there is a danger that foresters could end up being unable to participate effectively in this contemporary conservation debate. Those entangled in forestry 
research should be actively refocusing at least some attention on rewilding - bringing the debate within the pages of core journals and engaging it with core practices and strategies. This engagement may enable foresters to stop rewilders reinventing tried and tested wheels, whilst rewilders might shake foresters out of their straight and narrow trees!

\section{References}

Arts, K., Fischer, A. \& van der Wal, R. 2015. Boundaries of the wolf and the wild: a conceptual examination of the relationship between rewilding and animal reintroduction, Restoration Ecology, 24: 27-34

Biermann, C. \& Anderson, R. M. 2017. Conservation, biopolitics, and the governance of life and death. Geography Compass, 11(10) e:12329

Browning, G. 2019. Rewilding, the view from a Wilder Lake District Valley, Quarterly Journal of Forestry, 113: 129-134

Ceaușu, S., Hofmann, M., Navarro, L.M., Carver, S., Verburg, P.H. and Pereira, H.M. 2015. Mapping opportunities and challenges for rewilding in Europe. Conservation Biology, 29: 1017-1027

Drenthen, M. 2018. Rewilding in Cultural Layered Landscapes, Environmental Values, 27, 325-330

Foreman, D., 2004. Rewilding North America: a vision for conservation in the 21 st century. Island Press.

Fisher, M. \& Parfitt, A. 2016. The challenge of wild nature conserving itself. ECOS, 37, 2734.

Gobster, P. H. 1999. An Ecological Aesthetic for Forest Landscape Management. Landscape Journal, 18: $54-64$

Gammon, A. 2018. The Many Meanings of Rewilding. Environmental Values 27, 331-340

Harmer, R. \& A. Kiewitt. 2005. Restoration of lowland conifer PAWS, Annual Report and Accounts, Forest Research, Farnham

Hayward et al. 2019. Reintroducing rewilding to restoration - Rejecting the search for novelty, Biological Conservation, 233: 255-259

Jepson, P. 2015. Time to walk the talk, Geographical Magazine, $24^{\text {th }}$ November 2015, http://geographical.co.uk/opinion/item/1402-time-to-walk-the-talk

Jepson, P. (2016) Rewilding needs an enabling policy environment. Geographical Magazine, $24^{\text {th }}$ May 2016, http://geographical.co.uk/opinion/item/1703-rewilding-needs-an-enabling-policyenvironment 
Jepson, P. \& Schepers, F. 2016. Making space for rewilding: creating an enabling policy environment. Policy Brief Rewilding Europe

Jørgensen, D. 2015. Rethinking rewilding. Geoforum, 65: 482-48

John Muir Trust 2015. Rewilding: Restoring ecosystems for nature and people. https://www.johnmuirtrust.org/assets/000/000/397/rewilding_policy agreed0315 published original.pdf?1434628289

Lorimer, J. and Driessen, C. 2013. Bovine biopolitics and the promise of monsters in the rewilding of Heck cattle. Geoforum, 48: 249-259

Lorimer, J. and Driessen, C. 2016. From "Nazi cows" to cosmopolitan "ecological engineers": Specifying rewilding through a history of Heck cattle. Annals of the American Association of Geographers, 106: 631-652

Lorimer, J., Sandom, C., Jepson, P., Doughty, C., Barua, M., \& Kirby, K. J. 2015. Rewilding: Science, practice, and politics. Annual Review of Environment and Resources, 40: 39-62

Malesios, C. and G. Arabatzis (2012) An evaluation of forestry journals using bibliometric indices, Annals of Forest Research, 55: 147-164

Monbiot, G. 2013. Feral: Searching for enchantment on the Frontiers of rewilding. Penguin

Nesbit, R. 2018. What is wild?, The Niche, December 2018, 24-29

Pettorelli, N., Durant, S. \& du Toit, J. 2019. Rewilding. Cambridge University Press

Prior, J., \& Brady, E. 2016. Environmental aesthetics and rewilding. Environmental Values, 26: $31-51$

Rewilding Britain 2017. Rewilding Principles.

http://www.rewildingbritain.org.uk/rewilding/rewilding-principles

Sandom, C. and Wynne-Jones, S. 2019. Rewilding a Country: Britain as a Case study, in Pettorelli, N., Durant, S. \& du Toit, J (eds) Rewilding. Cambridge University Press.

Stanturf, J.A., B.J. Palik, \& R.K. Dumroese. 2014. Contemporary forest restoration: a review emphasizing function, Forest Ecology and Management, 331: 292-323.

Torres, A., Fernández, N., zu Ermgassen, S., Helmer, W., Revilla, E., Saavedra, D., Perino, A., Mimet, A., Rey-Benayas, J.M., Selva, N. and Schepers, F., 2018. Measuring rewilding progress. Philosophical Transactions of the Royal Society B: Biological Sciences, 373(1761), p.20170433.

Vanclay (2008) Ranking forestry journals using the h-index, Journal of Infometrics, 2: 326334

Ward, K. 2019. For wilderness or wildness, in Pettorelli, N., Durant, S. and du Toit, J (eds) Rewilding. Cambridge University Press. 
Wentworth, J. \& Alison, J. 2016. Rewilding and Ecosystem Services. Parlimentary Office of Science and Technology.

http://researchbriefings.parliament.uk/ResearchBriefing/Summary/POST-PN-0537\#fullreport

Woodland Trust 2017. Rewilding: Working with nature. Available online:

https://www.woodlandtrust.org.uk/publications/2017/07/rewilding/

Wynne-Jones, S., Strouts, G. \& Holmes, G. 2018. Rewilding in Wales: Reimagining or Abandoning a Cultural Heartland? Environmental Values. 27: 377-403 